\title{
THE CHANGING CLIMATE AND THE ARCTIC COASTAL SETTLEMENTS
}

\author{
OVE T. GUDMESTAD \\ Department of Mechanical and Civil Engineering \\ and Materials Science, University of Stavanger, Stavanger, Norway
}

\begin{abstract}
The changing climate has led to increased summer temperatures in the Arctic, later sea ice formation in the fall season and less ice during the winter. Parts of the icecap are thinning and during summer, the area covered by ice has been shrinking. This situation has led to open seas and longer wind fetch, so larger waves build up during the late summer and fall seasons. This situation is then associated with larger waves hitting the Arctic coastline. The larger waves are influencing the shores where melting of permafrost occurs to a larger extent than previously and the consequences are large erosion and retracting of the coastline.

Furthermore, as the open sea and the shallow waters in the near coast areas over most of the Arctic cause large storm surge effects, the associated flooding is more pronounced than before, associated with damages far inland. Adding a general slow water level increase, the Arctic coastal shoreline is under pressure. The situation for Alaskan as well as Russian settlements is being discussed. The consequences of the situation are a need for local strengthening of the coastline artificially and subsequent relocation of Arctic coastal settlements.
\end{abstract}

Keywords: Arctic settlements, erosion of shoreline, ice limit, permafrost-melting, waves

\section{INTRODUCTION}

The Arctic Ocean is normally considered a hazardous environment and, because of lack of historical and scientific data, the weather is difficult to predict. Certain weather phenomena like polar low pressures generated in the zone between the ice cover and the open water are particularly difficult to forecast due to the unstable nature of the air in these areas.

Northern areas have recently experienced considerable flooding, caused by combined storm waves, surges and tides, as was the case in the Varandey area in northern Russia on 24 July 2010, when the oil treatment and storage terminal located kilometres inland was flooded and the airport runway close to the coast was severely damaged.

Furthermore, the Northstar artificial oil and gas production island in the Beaufort Sea, $19 \mathrm{~km}$ northwest of Prudhoe Bay, Alaska, and $10 \mathrm{~km}$ north of the Alaskan coast at a water depth of $10 \mathrm{~m}$, was severely damaged by large waves. This happened during the first decade of the 21st century due to longer fetch lengths and larger waves than anticipated in the design phase.

In this article, we are concerned with changes in the Arctic climate. The Arctic region is one of the areas that is most influenced by climatic changes. For example, the ice coverage percentage shrank from 7.5 million $\mathrm{km}^{2}$ in 1978 to about 3 million $\mathrm{km}^{2}$ in 2012 (see Fig. 1, from [1]). In places where there used to be permanent ice throughout the year, now we see waves of up to several metres in height.

\section{THE EFFECT OF LACK OF ICE-COVER}

Wind blowing over a sea surface generates ocean surface waves (wind-sea and swell waves) which are related to the distance (length of fetch) and the strength and duration of the wind. As both wind-sea and swells depend on the open water sea fetch length (the distance over which the wind blows), further reductions in seasonal ice cover will result in larger waves [2]. 


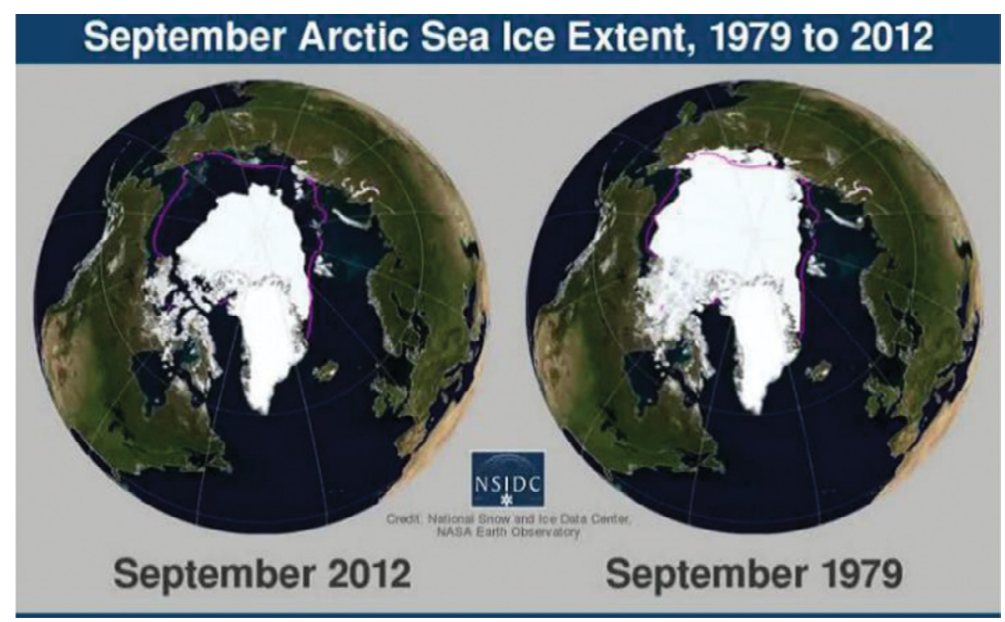

Figure 1: The influence of climate change on the ice coverage in the Arctic from 1979 to $2012[1]$.

Apart from the deep parts of the ocean, surface waves, when they come to shallow waters close to the coast, generate currents and force circulation that can cause erosion, resulting in sediment transportation. Waves generated by rapid storms can also be hazardous for navigation and operations at sea, either for fishing or for oil- and gas-related activities. In the Arctic Ocean, wave conditions like those are becoming more and more significant for nature and humans, changing the known environment.

The calculation of wave height and period as function of fetch length (in accordance with US Army Coastal Engineering Manual [3]) is described below:

1. Calculation of the frictional wind velocity

$$
u_{*}=W \sqrt{0.001(1.1+0.035 W)}
$$

Where:

$W=$ mean velocity at $10 \mathrm{~m}$ height

2. Calculation of the equivalent fetch, $F_{e q}$, depending on the duration of the wind:

$$
\frac{g F_{e q}}{u_{*}^{2}}=0.00523\left(\frac{g t_{d}}{u_{*}}\right)^{1,5}
$$

Where:

$g$ is the gravity acceleration, $9.81 \mathrm{~m} / \mathrm{s}^{2}$

$t_{d}$ is the duration of the wind blowing

$F_{e q}$ is the equivalent fetch length

3. Checking whether the wave is duration or fetch limited:

If $F_{e q}>F$ then the wave is fetch limited and the fetch, $F$, of the specific direction, needs to be used for the calculation of the characteristic height, $H_{\text {s }}$.

If $F_{e q}<F$ then the wave is duration limited and the $F_{e q}$ should be used for the height calculation. 
4. Calculation of the characteristic wave height

$$
\begin{aligned}
& \frac{g H_{\mathrm{s}}}{u_{*}^{2}}=0.0413\left(\frac{g F}{u_{*}^{2}}\right)^{0,5} \\
& \frac{g H_{\mathrm{s}}}{u_{*}^{2}}=0.0413\left(\frac{g F_{e q}}{u_{*}^{2}}\right)^{0,5}
\end{aligned}
$$

$H_{\mathrm{s}}$ is the characteristic significant wave height

5. Calculation of the characteristic period of the wave

$$
\frac{g T_{\mathrm{s}}}{u_{*}}=0.71345\left(\frac{g F}{u_{*}^{2}}\right)^{0,33}
$$

$T_{\mathrm{s}}$ is the characteristic wave period

For a discussion of the estimated waves in an open Arctic without ice cover, see [4].

\section{THE CASE OF KIVALINA: CHUKCHI SEA}

The settlement of Kivalina, Figs. 2 and 3, is located at the tip of an 8-mile barrier reef located between the Chukchi Sea and Kivalina River. According to BBC News [5], the US Army Corps of Engineers has estimated that Kivalina will be uninhabitable in 2025. The Arctic is warming faster than the global average, so sea ice is forming on the Kivalina coastline later in the year and melting faster in the spring and summer. The lack of sea ice makes the island vulnerable to erosion from storms that occur regularly in the fall. Lack of sea ice also means warmer waters, which increase the severity of storms that hit the island.

For a further discussion of the plans to relocate the settlement, see $[6,7]$.

Similar challenges as the problems met in Kivalina are also experienced in the most northerly tip of US territory, in the town of Barrow (see map Fig. 2). The residents of the town have large problems thanks to climate changes. In March, 2016, the sea ice began to melt and break up. After eventually refreezing, it was so unstable that the inhabitants were unable to hunt for whales and seals, thus wrecking their hunting season. Further effects of erosion are discussed in [8]. A particular phenomenon is that freshwater reservoirs located away from the ocean are close to being flooded due to erosion and high seas.

\section{THE CASE OF VARANDEY: PECHORA SEA}

The settlement of Varandey is located in Pechora Sea, Northwest Russia; see Fig. 4. An onshore processing terminal and an offshore offloading terminal are located in this area. The coastlines are exposed, and the permafrost melts during the summer and is eroded during late summer and fall prior to refreezing.

Two Norwegian/Russian expeditions $[9,10]$ carried out fieldwork investigating the conditions and erosion of the coastal zone during 2012 and 2013. These field investigations were combined with remote sensing analysis of coastal erosion rates in Varandey since 1961 with satellite images analysis. Between 2005 and 2010, 28 buildings disappeared in the settlement due to coastal retreat with erosion rates up to $7.4 \mathrm{~m} /$ year at some place but an average $2.7 \mathrm{~m} /$ year. The average erosion of a segment of the Medynskiy peninsula (composed of a 5-15 m 


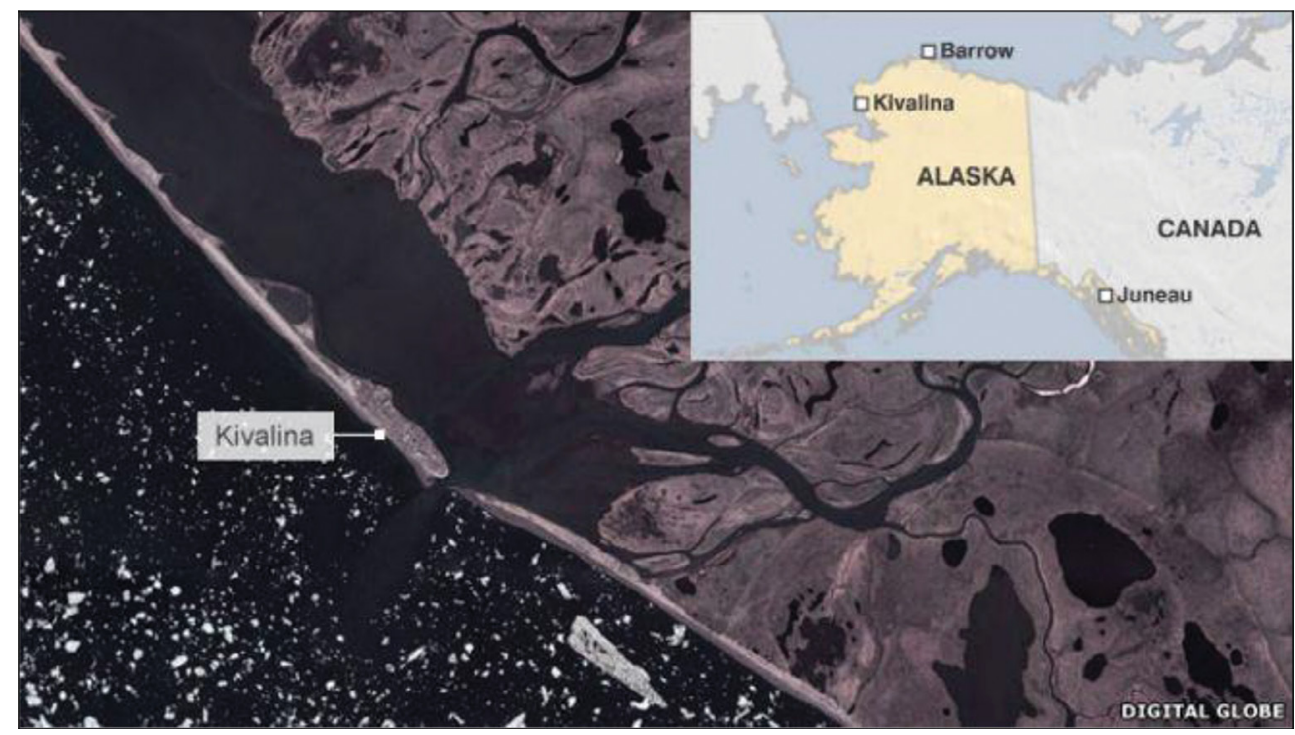

Figure 2: Location of Kivalina [5], http://www.bbc.com/news/magazine-23346370.

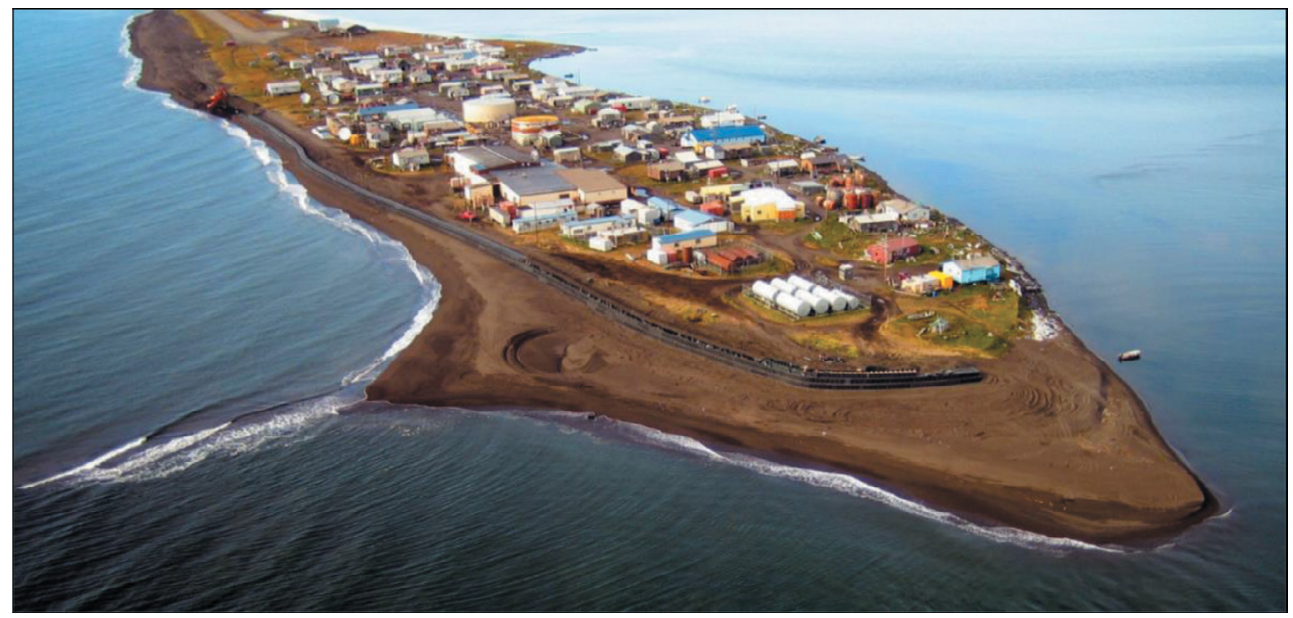

Figure 3: The village of Kivalina, Alaska [5], http://www.bbc.com/news/magazine-23346370.

high marine terrace with dense ice and marine loams and clays) was 2,8 m/year from 1990 to 1998 and $1,8 \mathrm{~m} /$ year between 1998 and 2010 . Over a $15 \mathrm{~km}$ long segment the erosion was 19.6 m during the season between 2010 and 2011, following a storm surge in the area in summer 2010.

Russian scientists from Lomonosov Moscow State University investigated coastal dynamics of several sites along the Russian Arctic coast, Fig. 4 [11]. Emphasis on the erosion of the Varandey coast (Fig. 5) shows considerable erosion, as was also reported by [9] and [10]. Figure 6 shows a heavily eroded shoreline of the Kara Sea coast [11]. 


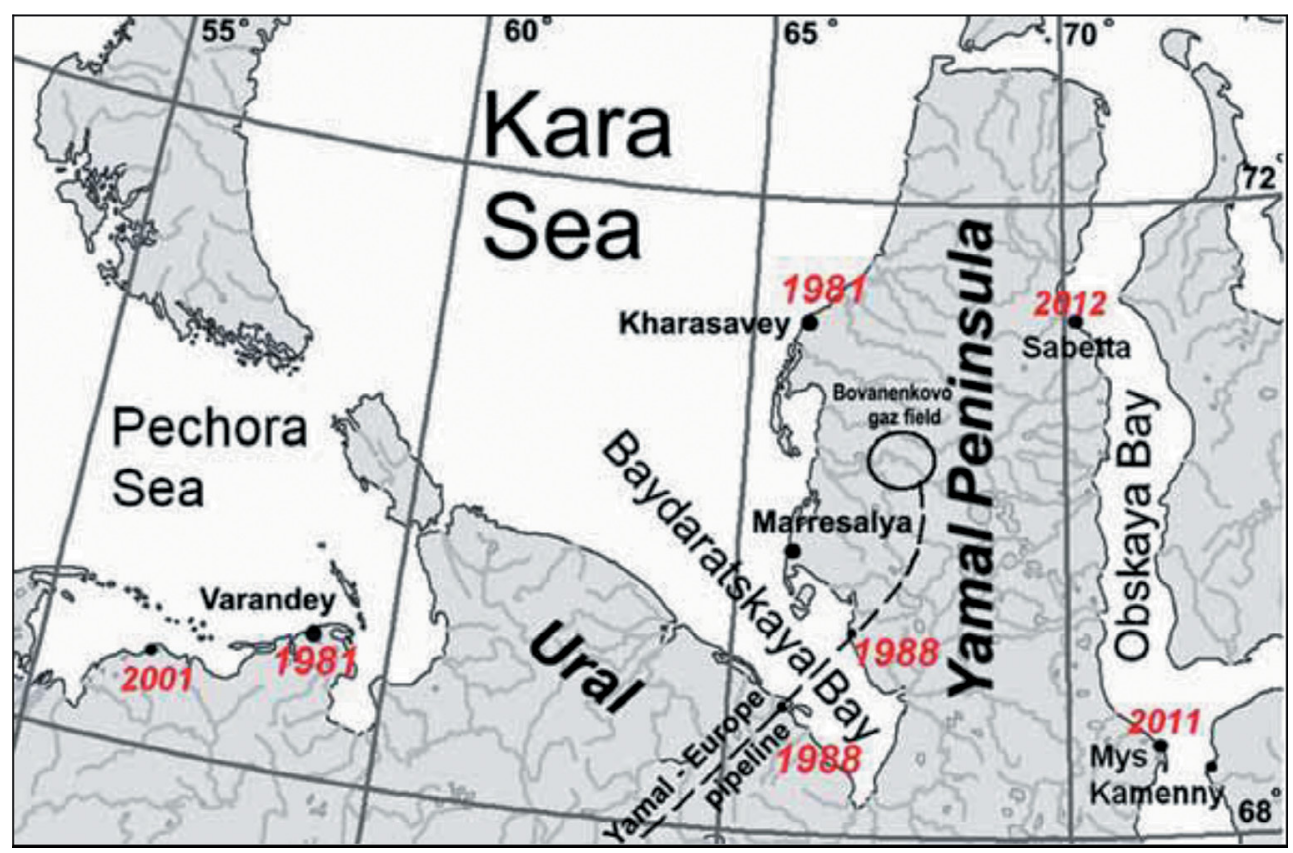

Figure 4: Key sites for studies in ref [11]. The ear of the start of the observations is given.

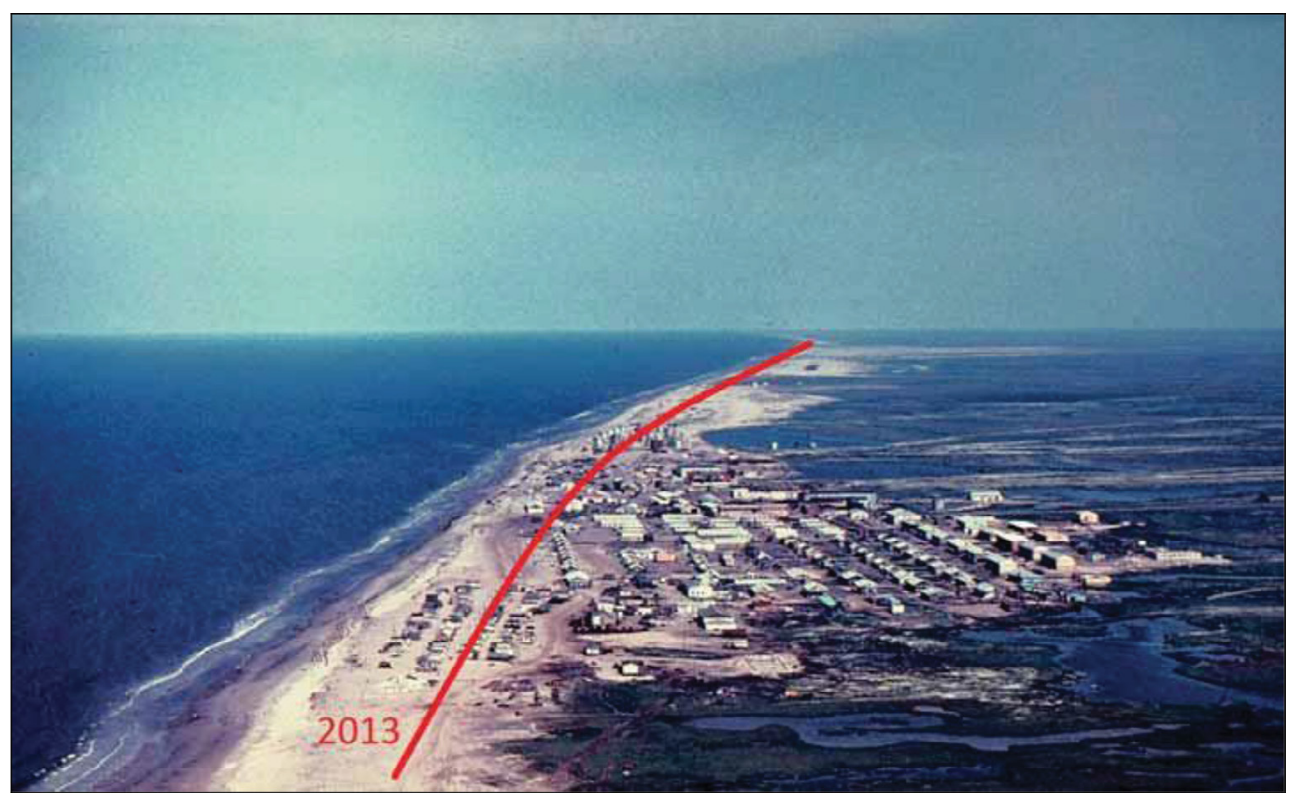

Figure 5: Aerial photo of the Varandey settlement at 1985; coastline of 2013 (Russian Geographic Society [11]). 


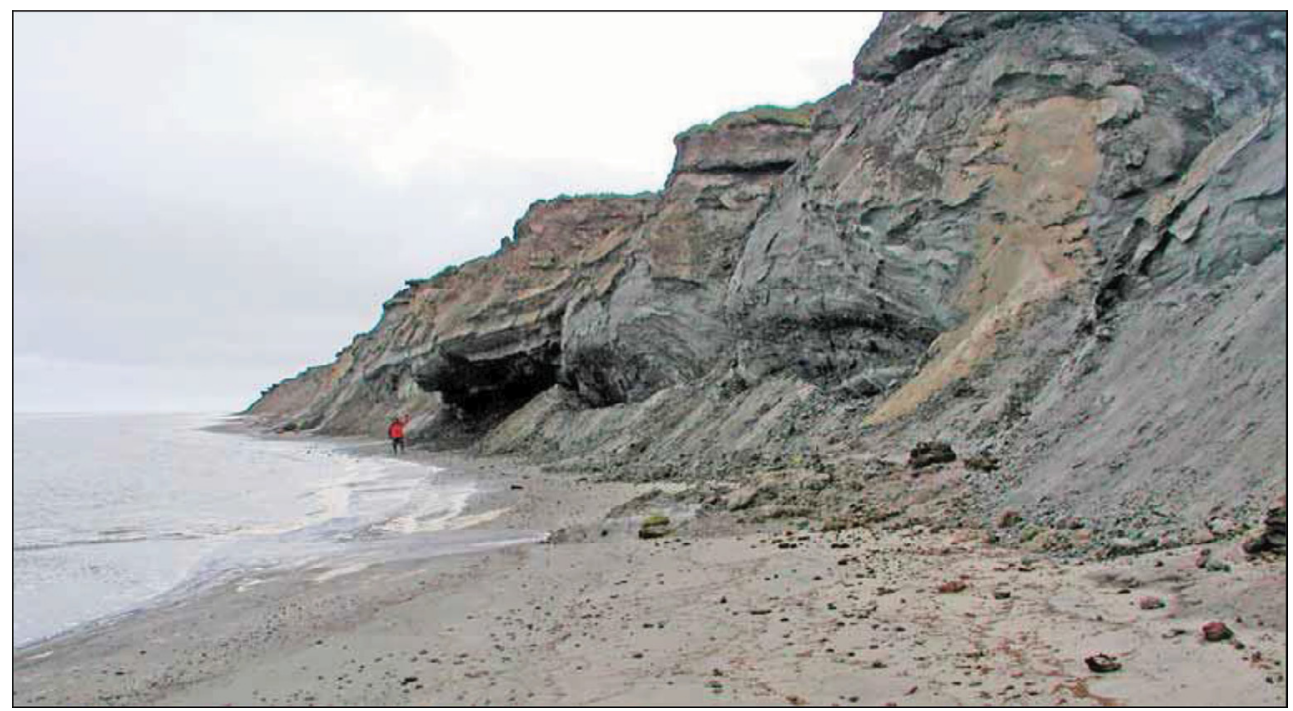

Figure 6: Typical eroded coast of the Kara Sea [11].

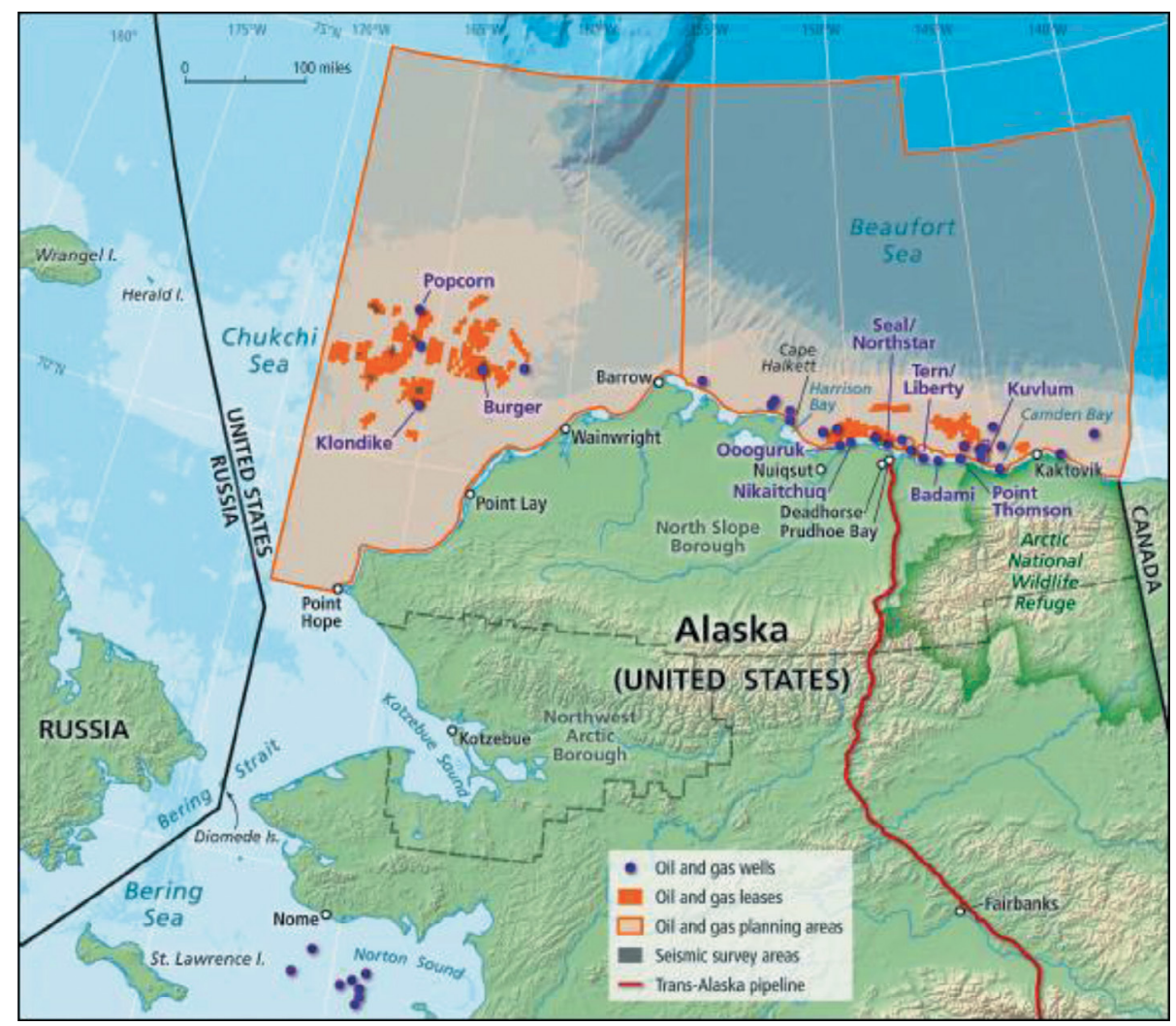

Figure 7: Location of oil and gas leases North Alaska. 


\section{THE CASE OF NORTHSTAR OIL PRODUCTION ISLAND}

The 5-acre Northstar artificial oil and gas Production Island (built 1999) is located 6 miles offshore in water depths of $12 \mathrm{~m}$ in the Beaufort Island north of Alaska, Fig. 7. The production island consists of 1.6 million tons of gravel. It is protected a sheet pipe wall, and there is a gradual slope to still water level, Fig. 8. The production is flowing through a subsea pipeline to shore [12]. During the first decade of this century, the island was heavily damaged by waves hitting the production equipment [13]. The design condition expected that ice would form on the sea, protecting the island from the waves during the fall storms. The year when ice formed late, waves were forming, causing considerable damage to the facilities.

\section{THE CASE OF LONGYEARBYEN, SVALBARD}

Longyearbyen, Spitsbergen, is another settlement where the changing climate is causing challenges due to increased permutation [8]. During the latest years the winter temperatures have for certain periods been much higher (up to 20 degrees $C$ ) than the average over the past, and moist air has been flowing in the northern direction during winter, causing snowfall that was uncommon in the past. The snow accumulations have caused avalanches with fatal outcome [15]. The settlement was not prepared for such events, Fig. 9, and the local building code did not account properly for avalanches. It is probable that a large number of houses must be abandoned due to the potential for larger snowfalls and subsequent unstable snow accumulations.

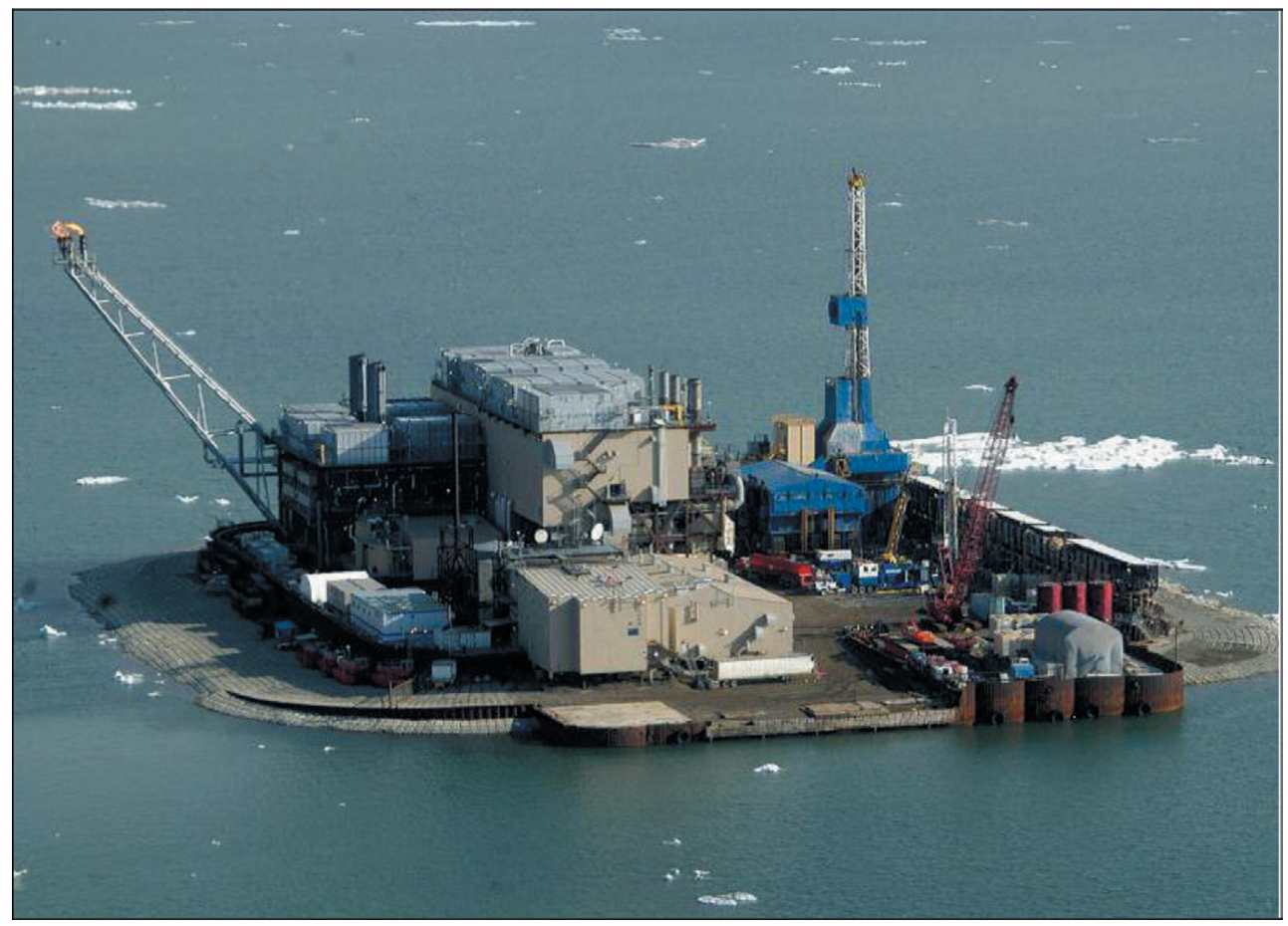

Figure 8: The Northstar Oil and Gas Production Island [14]. 


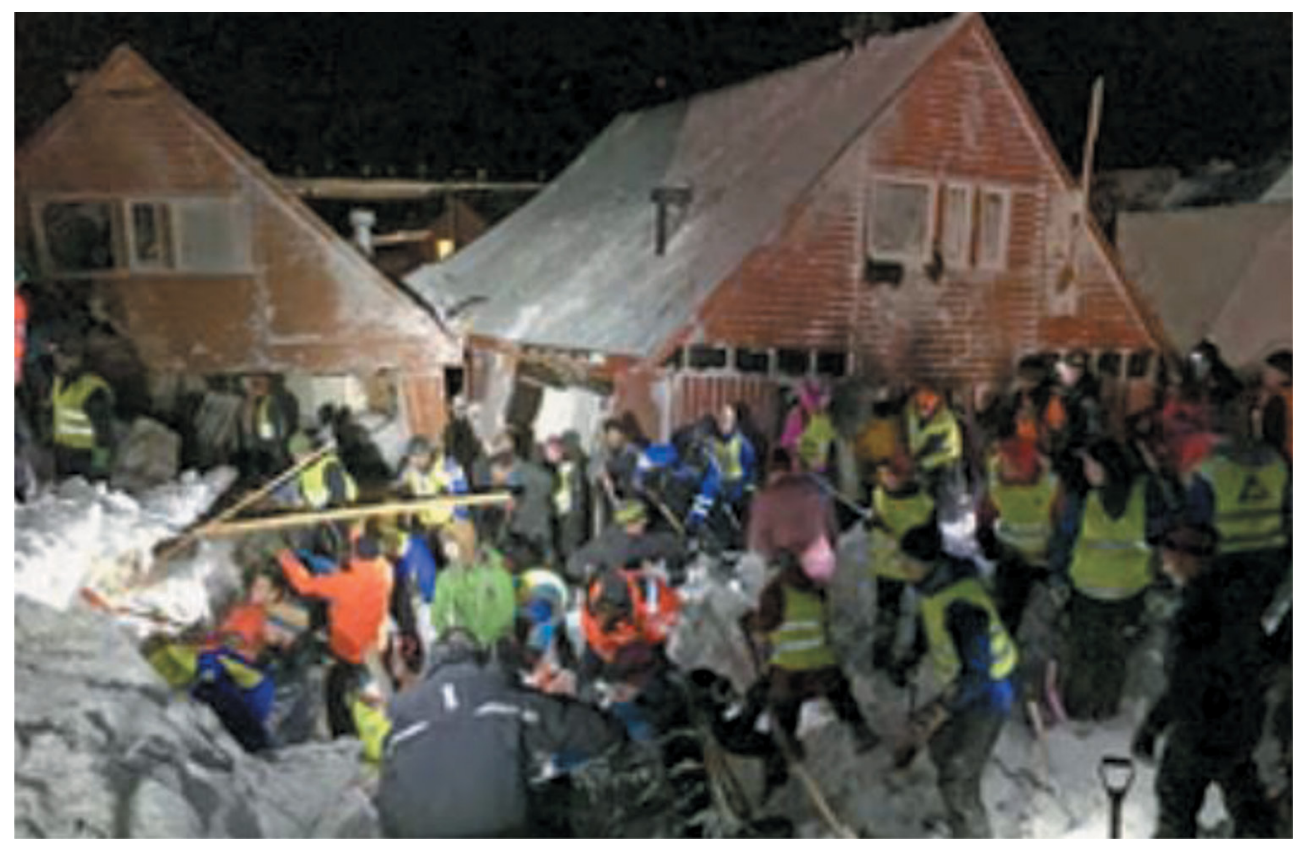

Figure 9: Search crews with shovels worked to free people from buried houses after an avalanche hit several houses in Longyearbyen, Norway. Photograph: STRINGER/ EPA [15].

\section{CONCLUDING REMARKS}

The changing climate has a large influence on low-lying coastal settlements and offshore oil and gas facilities located on artificial islands. The lack of, or limited, ice cover causes a challenging situation during the fall and winter seasons when winds generate large waves. A combination of storm surges and wind waves cause erosion of shorelines when warm summers have caused melting of the permafrost layers. For some Arctic settlements, the situation is dramatic. The settlements may be abandoned over time as the distance between the ocean and the built infrastructure is shrinking. Furthermore, freshwater reservoirs are in danger, also because of thawing permafrost and the possibility that these reservoirs be filled with seawater. Plans for resettling Arctic coastal settlements are presently being developed.

Engineering solutions, such as shoreline protection by breakwaters or sheet piling or use of geobags [7], may be successful only to a limited extent as the shoreline to be protected in many cases are very low lying, and it will be extremely costly to protect the settlements adequately. Furthermore, all engineering solutions will have to be founded on the melting permafrost whereby the solutions will require heavy maintenance as the foundation support vanishes.

\section{REFERENCES}

[1] Rogers, W.E., Marchenko, A. \& Babanin, A.V., Energetic surface waves measured in arctic ice. Proceedings from UNO Waves Meeting, University of New Orleans' Oliver St. Pé Center: New Orleans, Louisiana, USA, 2015.

[2] Thomson, J. \& Rogers, W.E., Swell and Sea in the Emerging Arctic Ocean, AGU Publications, Applied Physics Laboratory, University of Washington, Naval Research Laboratory: Seattle, Washington, DC, 2014. 
[3] Kostopoulos, D. \& Gudmestad, O.T., Extreme waves generated in a future Arctic Ocean. Presented at IEEE International Conference on Industrial Engineering and Engineering Management (IEEM), November 2015, Singapore.

[4] U.S. Army, Coastal Engineering Manual. Chapter II-2, Meteorology and Wave Climate, Engineer Manual 1110-2-11000, U.S. Army Corps of Engineers: Washington, DC, 2006.

[5] BBC News, available at http://www.bbc.com/news/magazine-23346370, 30 July 2013 (accessed 1st April 2017).

[6] Northwest Arctic Borough, available at http://www.nwabor.org/village/kivalina/ (accessed 1st Apil 2017).

[7] Walsh, M, available at https://www.yahoo.com/news/kivalina-alaska-climate-changearctic-circle-global-warming-relocate-ice-184202379.html?ref=gs, 2015 (accessed 1st April 2017).

[8] Gudmestad, O.T, Cold region hydrology. Handbook of Engineering Hydrology, ed. Said Eslamian, CRC Press, Taylor and Francis, Boca Raton, Florida, USA. ISBN 9781466552418, 2014.

[9] Sinitsyn, A. \& Guegan, E., Investigations of coastal erosion rates and mechanisms in Varandey Area, Barents Sea, Book of Abstracts of EUCOP4 - 4th European Conference on Permafrost, 18-21 June 2014, Évora, Portugal, p. 276.

[10] Sinitsyn, A., Guégan, E., Kokin, O., Vergun, A., Udalov, L. \& Ogorodov, S., Investigations of coastal erosion processes in Varandey Area, Barents Sea. Proceedings of SPE Conference, Arctic and Extreme Environments, Society of Petroleum Engineers: Moscow, 2013. DOI: $10.2118 / 166932-R U$.

[11] Ogorodov, S.A., Baranskaya, A.V., Belova, N.G., Kamalov, A.M., Kuznetsov, D.E., Overduin, P.P., Shabanova, N.N. \& Vergun, A.P., Coastal dynamics of the Pechora and Kara Seas under changing climatic conditions and human disturbances, Geography, Environment, Sustainability, Vol. 09(3), Issued by Russian Geographical Society, Lomonosov Moscow State University, Moscow, Russia, pp. 53-73, 2016.

[12] BP, available at http://www.bp.com/content/dam/bp-country/en_us/PDF/2014-NorthernReport.pdf (accessed 1st Aril 2017).

[13] Confidential information given by BP employees regarding damages to the Northstar production facilities, Alaska (accessed 1st April 2017).

[14] Bureau of Ocean Energy Management, available at https://www.boem.gov/AboutBOEM/BOEM-Regions/Alaska-Region/Leasing-and-Plans/Plans/BP-North-Star.aspx.

[15] The Guardian, Fatal avalanche buries houses in Norway's Arctic Svalbard archipelago, available at https://www.theguardian.com/world/2015/dec/20/fatal-avalanche-burieshouses-in-norways-arctic-svalbard-archipelago, 20 December 2015 (accessed 1st April 2017). 